\title{
Nutritional and Bioactive Compounds of Soybean: Benefits on Human Health
}

\author{
Hércia Stampini Duarte Martino, Leandro de Morais Cardoso, \\ Sônia Machado Rocha Ribeiro, Maria Inês de Souza Dantas, \\ Newton Deniz Piovesan and Elvira De Mejía \\ Nutrition and Health Departament, Universidade Federal de Viçosa \\ Department of Food Science and Human Nutrition \\ University of Illinois, Urbana-Champaign, Il

\section{Introduction}

The soybean (Glycine Max. (L) Merrill) is a leguminous which originated from China and has been cultivated in this country for around five thousand years. It was considered for centuries the staple food of the countries of East Asia. In the West, its introduction was made experimentally in the Europe in 15th century. In the USA the first reports of cultivation of soybean date from 1765. Unlike East Asia, the USA soybean was initially cultivated as forage plant being used as a source of edible oil starting at 1915. A major technological progress for the use of soybean meal as protein source in nutrition was made in 1917, when Osborne and Mendel demonstrated that unheated soybean meal presents nutritional quality lower than that of heated soybean meal. Thus, the finding of the nutritional value of soybean meal as a feed for animal nutrition, coupled with growing demand for vegetable oils allowed the deployment of many industries for the processing of soybeans in the USA (Müller, 1981).

In Brazil, the introduction of soybeans occurred in Bahia state, in 1882 (Bonetti, 1981). But the first statistics showing the use of soybean for grain production are from 1941. In this same year, the first soybean processing industry in the country was installed in Rio Grande do Sul (Teixeira, 2003). However, only from the 1960, soybean crop became important in the country, initially in the South where it showed better adaptation because of the similarity with regions of cultivation in southern United States. From the 70's, the soybean crop has evolved significantly in the cultivation states, not only in the south, but also in the middle western of Brazil. With the development of new cultivars adapted to different agro-climatic regions of the country, Brazil has become the second largest soybean producer in the world. Advances in new technologies for increased acceptability of soy proteins as human food occurred as result of protein deficiency worldwide, after the World War II. Since the 1950's, USA and Canadian public research institutions worked on the development of soybean cultivars for human food use for export, mainly to Japan. In 1999, there were 16 breeding programs in public institutions working on soybean for human consumption (food-type). By 
1998, dozens of cultivars had been launched specifically for the production of Tofu, Edamame and Natto. In the domestic market, only from mid-1980 genetic breeding became important in reducing the beany flavor, which is the factor that contributes more to low acceptability of soybeans as food.

In the 70s Brazil implemented a series of government programs for the introduction of a soybean beverage in school lunches, but this product was not well accepted because of its unpleasant taste resulting from the use of an inappropriate processing technology and inappropriate soybean cultivars. This led to the failure of this initiative and the deactivation of almost all programs, which reduced for a long time the possibility of using soybeans for human consumption.

The lack of a cultivar more suited to Western market has an explanation in the evolution of the low acceptability of soybean grown in Brazil, as well as in the USA. Soybean was initially grown as a forage plant, then as grain for oil extraction and only in 1960 as a source of protein meal. The development of flavored cultivars, more suited to the Western palate, was never a priority. Hence, the lack of cultivars adapted for this purpose. The cultivars used until this time point had undesirable taste and odor called beany flavor. The beany flavor derives from the formation of hydroperoxides as a result of the degradation of polyunsaturated fatty acids resulted from the action of lipoxigenases enzymes. The heat inactivation of lipoxygenases during the processing of soybean has been used in the food industry to reduce the beany flavor. Several treatments are recommended; however, they promote denaturation of proteins, altering their functional properties. This fact, coupled with the inefficiency of the thermal treatment to completely eliminate the beany flavor encouraged several groups of researchers in the country and abroad to find instead a genetic solution to the problem.

Mindful of the need to adjust the taste of soybean to the Western consumer, testing began in Brazil in 1982, in partnership with foreign researchers, in order to identify soybean genotypes that have a lower beany flavor. So, productive cultivars without lipoxygenase and very low levels of other related compounds to beanny flavor have been developed. Research conducted at the Universidade Federal de Viçosa, Brazil, has led to the development of five cultivars devoided of lipoxygenases in the seeds, and also considered as productive cultivars (Cultivars UFVTN 101, UFVTN 102, UFVTN 103, UFVNT 104 and UFVTN 105). These cultivars are currently being recommended for planting in the state of Minas Gerais. Other aspects relating to quality of soybean, of great relevance for the food industry, subject of genetic improvement, are: higher content and quality of protein, lower oligosaccharides content (stachyose, raffinose and verbascose), higher contents of isoflavones, oleic acid and lower levels of linolenic acid, and absence of inhibitors of protease and lectins (Moreira, 1999). Several cultivars that meet these characteristics are now under development, among them, some derived of UFVTN 105, that besides their absence of lipoxygenases, may contain either high protein (UFVTN 105 AP), low-linolenic acid (UFVTNC 106) or high protein content, and lack of KTI and lectin (UFVTNK 107).

Another improvement program for creation of cultivars destined to human feeding has been developed by Empresa Brasileira de Pesquisa Agropecuária - Soja (EMBRAPA Soja) since 1987. With the aimed of searching for cultivars with more suitable characteristics for food processing, such as good appearance (clear integument and hilum) and mild flavor, among others, EMBRAPA Soja released the following cultivars: BRS 155, which features low content of trypsin inhibitor; BRS 213, which does not contain lipoxygenase enzymes; BRS 216, which has grains of small size, suitable for the production of sprouts and natto; BRS 257, which does not contain lipoxygenase; BRS 267, which has a higher sugar content, and BRS 258, destined to the organic system. 
In the private sector the company Naturalle Agro Mercantil Ltda works in the commercialization of special soybean for human consumption and aimed for export. Several cultivars (NT2; NT4, NT10, NT12, among others) with differentiated characteristics of grain size, with clear colors of integument and hilum, and high levels of protein have been already developed.

Traditionally, soybean is not consumed raw. Studies have shown the importance of using appropriate techniques of preparation, preservation and improvement of their nutritional and sensory characteristics. Traditional methods of preparation of soybean for human consumption include germination, cooking, roasting, and fermenting, in order to inactivate thermolabile antinutrients e.g. trypsin and chymotrypsin inhibitors and lectins (Reinwald et al., 2010).

Regarding heat treatment, there is not a recommendation of the best time and temperature to be applied to the grains in order to inactivate and, or reduce their phytochemicals which have antinutricional effects, in detriment of those with functional or beneficial effects. Adequate levels of urease activity have been demonstrated in soybeans subjected to a temperature of 98 ${ }^{\circ} \mathrm{C}$ for 30 minutes under humid heat, $60^{\circ} \mathrm{C}$ for 42 hours, $150{ }^{\circ} \mathrm{C}$ for 30 minutes and $121^{\circ} \mathrm{C}$ for 15 minutes under dry heat indicating denaturation of trypsin inhibitor (Machado et al., 2008). Moreover, the temperature of $150^{\circ} \mathrm{C}$ for 30 minutes promotes the dephosphorylation of phytic acid, reducing the concentrations of inositol pentaphosphate and hexa, which have antinutritional action, without affecting the concentration of inositol triphosphate and tetra, which are phytochemicals with antioxidant properties (Andrade et al., 2010).

As soybean consumption increases in the Western diet, it is more common to find foods containing soy components rather than whole soy. Soy flour is the soy products less refined, however it is the industrialized most important soy product, since it is used to enrich foods, and for manufacturing textured, concentrated and isolated proteins. The incorporation of soy flour to replace wheat flour in formulation of bakery products increases the nutritional value of these products, especially the levels of protein, lipids, fiber and minerals when compared to conventional product (Dantas et al., 2009). The acceptance of formulations using mixed flours of wheat and soybeans suggests that the use of soy flour, obtained from cultivars without lipoxygenase, minimizes the unpleasant sensory problems which are characteristics of soybean (Dantas et al., 2010).

The use of soybean for human consumption in the form of integral flour is a nutritional and technological advantage, since it presents greater contents of total dietary fiber and iron than soybean hull-less flour (Carvalho, 2009).

\section{Chemical composition and nutritional value of soybean}

In general, soybean cultivars have approximately $8 \%$ bark, $90 \%$ cotyledon, which contains the highest percentage of proteins and lipids, and $2 \%$ hypocotyledon. The soybean chemical composition and its structural parts vary according to cultivar, growing season, geographic location and environmental stress (Ciabotti et al., 2006).

Protein is the major constituent of the soybean (30 to $50 \mathrm{~g} / 100 \mathrm{~g}$ ), followed by carbohydrates ( 20 to $35 \mathrm{~g} / 100 \mathrm{~g}$ ) and lipids (15 to $25 \mathrm{~g} / 100 \mathrm{~g}$ ) (Carvalho et al., 2011; Esteves et al., 2010; Felix \& Canniatti-Brazaca, 2008; Machado et al., 2008; Martino et al., 2007; Oliveira et al., 2007; U.S. Department of Agriculture, 2009). However, commercially, carbohydrates are less important than the proteins and lipids (Liu, 1997). There is an inverse relationship between the protein content and, contents of lipid and carbohydrate, thus the cultivars with greater protein content present a lower contents of lipids and carbohydrates (Table 17.1). 


\begin{tabular}{lllllll}
\hline Compounds & BRS 133 $^{\mathbf{a}}$ & BRS 258 $^{\mathbf{b}}$ & OCEPAR-19c $^{\mathbf{c}}$ & UFV-116 $^{\mathbf{d}}$ & UFVTN 105AP $^{\mathrm{e}}$ & USDA $^{\mathbf{f}}$ \\
\hline Protein & 37.4 & 42.3 & 41.1 & 39.4 & 46.2 & 39.9 \\
Lipid & 21.4 & 22.7 & 24.6 & 20.8 & 19.9 & 21.4 \\
Ash & 4.9 & 4.8 & 4.7 & 6.6 & 5.3 & 5.2 \\
Insoluble dietary fiber & 23.2 & 23.0 & 0.7 & 0.8 & 9.1 & nd \\
Soluble dietary fiber & 2.8 & 2.8 & 1.7 & 1.3 & 1.5 & nd \\
Total dietary fiber & 26.0 & 25.8 & 2.3 & 2.1 & 10.5 & 9.9 \\
Total carbohydrates & 36.3 & 30.1 & 28.0 & 23 & 13.8 & 32.3 \\
Linoleic (18:2) & 5.6 & 5.6 & 5.5 & 5.5 & 5.8 & 9.9 \\
$\alpha$-Linolenic (18:3) & 0.9 & 0.7 & 0.8 & 0.8 & 0.7 & 1.3 \\
\hline
\end{tabular}

nd: not determined; a Soybean with low protein content and with hull; b Soybean with high protein content and with hull (Paucar-Menacho et al., 2010); c Conventional soybean with hull thermally treated 80 $\mathrm{oC}$ for 20 minutes; d Soybean without LOX 2 and 3, hull-less, thermally treated $80{ }^{\circ} \mathrm{C}$ for 20 minutes (Esteves et al., 2010); e Soybean with high protein content without LOXs, with hull, thermally treated 150 ${ }^{\circ} \mathrm{C}$ for 30 minutes (Andrade et al., 2010); f Conventional soybean (U.S. Department of Agriculture, 2009).

Table 17.1. Chemical composition of conventional and genetically improved soybeans $(\mathrm{g} / 100 \mathrm{~g})$.

The main soluble carbohydrate of immature soybean is glucose. With the maturation of the grain, this sugar disappears, predominating non-reducing sugars such as sucrose, raffinose and stachyose (Paula, 2007). Most of the complex polysaccharides and oligosaccharides of the grain are composed of fibers, which are located mainly in cell walls and interstitial material of the shell (86\%). The cell wall of soybean contains about 30\% pectin, $50 \%$ hemicellulose and $20 \%$ cellulose. The grain also contains approximately $1 \%$ starch (Liu, 1997).

Soybean presents a high lipid content and is good source of essential fatty acids. In some soybean cultivars it has been observed they contain approximately $63 \%$ polyunsaturated fatty acid, 55\% linoleic acid and 8\% linolenic acid; 21.5\% monounsaturated fatty acid (oleic acid), and $15 \%$ fatty acids saturated, $11 \%$ palmitic acid and $4 \%$ stearic acid (Esteves et al., 2010). The linoleic acids $(\omega 6)$ and linolenic $(\omega 3)$ found in soybean are considered essential and are easily oxidized due to the presence of unsaturations. These fatty acids compete with the enzymes involved in the reactions of desaturation and chain elongation. Although these enzymes have a greater affinity for $\omega 3$ acids, the conversion of alpha-linolenic acid to polyunsaturated fatty acid of long chain is strongly influenced by levels of linoleic acid in the diet. Thus, the ratio between daily intake of foods rich in $\omega 6$ and $\omega 3$, such as soybeans, is very important in human nutrition (Martin et al., 2006).

The lipid fraction of grain contains vitamin E isomers, a-tocopherol (42.0 to $291.0 \mathrm{mg} / 100 \mathrm{~g})$, $\gamma$-tocopherol (79.0 to $252.0 \mathrm{mg} / 100 \mathrm{~g}$ ) and $\delta$-tocopherol $(27.0$ to $89.0 \mathrm{mg} / 100 \mathrm{~g}$ ) (Andrade, 2010; Baumgartner et al., 2010); and small amounts of vitamin $\mathrm{K}(47 \mathrm{mcg} / 100 \mathrm{~g})$ and vitamin A $(1.0 \mathrm{mcg} / 100 \mathrm{~g})$. There is also the presence of water soluble vitamins such as vitamin C $(6.0 \mathrm{mg} / 100 \mathrm{~g})$, folates $(375.0 \mathrm{mcg} / 100 \mathrm{~g})$, thiamin $(0.9 \mathrm{mg} / 100 \mathrm{~g})$, riboflavin $(0.3 \mathrm{mg} / 100 \mathrm{~g})$, pyridoxine $(0.5 \mathrm{mg} / 100 \mathrm{~g})$, niacin $(2.1 \mathrm{mg} / 100 \mathrm{~g})$ (Lebiedzinska \& Szefer, 2006; U.S. Department of Agriculture, 2009).

\subsection{Soy proteins}

Soybean is the legume that presents the highest protein content and thus contributes to the supply of essential amino acids and nitrogen to human and animals (Liu, 1997). The major components of soy proteins are storage proteins known as $\beta$-conglycinin (7S) and glycinin 
(11S), which represents $65 \%$ to $80 \%$ of total seed proteins. In addition, soybean contains are several inhibitors de proteases, lectins and enzymes (such as lipoxygenase and urease). Storage proteins can be classified according to their rate of sedimentation during centrifugation, as 2S, 7S, 11S, and 15S (Table 17.2). S means Svedberg unit, which is a unit of sedimentation rate computed as the rate of sedimentation per unit field of centrifugation strength (Wang \& De Mejia, 2005).

\begin{tabular}{|c|c|}
\hline $\begin{array}{l}\text { Ultrafiltration } \\
\text { protein fraction }\end{array}$ & $\begin{array}{l}\text { Percent in extractable Proteins in the fraction } \\
\text { protein }\end{array}$ \\
\hline $2 S$ & $\begin{array}{l}\text { Kunitz typsin inhibitors; Bowman-Birk typsin } \\
\text { inhibitors; Cytochrome C; AL1 and AL3a- } \\
\text { Conglycinin }\end{array}$ \\
\hline $7 S$ & $\begin{array}{l}\beta \text {-Conglycinin; } \gamma \text {-Conglycinin; } \alpha \text {-Amylase; } \\
\text { Lipoxygenase; Hemagglutinins (or lectins); } \\
\text { Soybean vacuolar protein P34 }\end{array}$ \\
\hline $11 S$ & Pure protein: glycinin \\
\hline $15 S$ & Pure protein: polymer of glycinin \\
\hline
\end{tabular}

a Adapted by: Wang et al.,(2005); b S = Svedberg unit. A unit of sedimentation rate computed as the rate of sedimentation per unit field of centrifugation strength.

Table 17.2. Soybean protein classification a

Soy proteins have high nutritional value and high concentration of lysine. This feature is important because of the its possible use in diets based on cereals, which are poor in lysine. In conventional cultivars sulfur amino acids are limiting, being methionine the most limiting one, followed by cystine and threonine (Liu, 1997). However, some genetically improved cultivars, such as the Brazilian cultivars BRS 133, BRS 258, OCEPAR-19, UFVTN 105 AP and UFV116, do not present this limitation (Carvalho, 2009; Esteves et al., 2010; Paucar-Menacho et al., 2010). In these cultivars, the breeding provided a qualitatively and quantitatively better balance of essential amino acids.

Genetic breeding is able of improve the profile of amino acids of soybean. However, the genetically improved cultivars may still present deficiencies of essential amino acids. By comparing the content of essential amino acids of soybean cultivars, with hull and hull-less (Table 17.3) with the standard of nutritional recommendations of FAO/WHO (2007), it was observed chemical scores above 1 for most of the essential amino acids. However, the cultivar UFVNT 105 AP was deficient in valine. Therefore, the development of new cultivars that meet the recommendations of essential amino acids is necessary.

The antigenic proteins, glycinin and $\beta$-conglycinin, may cause transient hypersensitivity reactions in the intestinal mucosa, especially in recently weaned animals, causing changes in the morphology of the intestinal mucosa with shortening of the villous and increased of the crypt depth. As a result, there may be a reduction in the number of mature enterocytes in villous, reduced villous height and increased of the crypt depth and thickness of inner and outer muscle, with consequent reduction of the digestive and absorptive capacity in the gut (Andrade et al., 2010; Caruso \& Demonte, 2005). However, fermentation can decrease soy immunoreactivity and can be optimized to develop nutritious hypoallergenic soy products. However, the clinical relevance of these findings needs to be determined by human challenge studies (Song et al., 2008). 


\begin{tabular}{lccccc}
\hline Amino acid & BRS 133 $\mathbf{a}$ & BRS 258 $\mathbf{b}$ & OCEPAR-19 $\mathrm{c}$ & UFV-116 $\mathrm{d}$ & UFVTN 105AP $\mathbf{~}$ \\
\hline & \multicolumn{5}{c}{ Indispensable } \\
Cystine & 0.72 & 0.71 & 0.62 & 0.72 & 0.66 \\
Histidine & 0.98 & 1.16 & 1.34 & 1.34 & 1.08 \\
Isoleucine & 1.66 & 1.90 & 2.32 & 2.66 & 1.97 \\
Leucine & 2.83 & 3.17 & 4.03 & 4.26 & 3.31 \\
Lysine & 2.30 & 2.58 & 2.94 & 3.25 & 2.77 \\
Methionine & 0.46 & 0.43 & 0.93 & 0.99 & 0.55 \\
Phenylalanine & 1.80 & 2.06 & 2.66 & 3.1 & 2.22 \\
Threonine & 1.47 & 1.56 & 1.99 & 2.2 & 1.77 \\
Triptophan & $\mathrm{nd}$ & $\mathrm{nd}$ & 0.86 & 0.73 & 0.59 \\
Tyrosine & 1.33 & 1.43 & 1.76 & 1.99 & 1.54 \\
Valine & 1.68 & 1.82 & 2.32 & 2.55 & 2.03 \\
\hline Total of indispensable & 15.24 & 16.82 & 21.77 & 23.79 & 18.49 \\
\hline & & Dispensable & & \\
Alanine & 1.61 & 1.81 & 2.21 & 2.36 & 1.92 \\
Arginine & 3.25 & 3.98 & 3.78 & 4.35 & 3.25 \\
Aspartic acid & 4.34 & 4.90 & 5.62 & 6.24 & 5.11 \\
Glutamic acid & 6.93 & 8.02 & 9.28 & 10.51 & 7.87 \\
Glycine & 1.91 & 2.09 & 2.03 & 2.24 & 1.88 \\
Proline & 1.86 & 2.11 & 2.51 & 2.64 & 2.38 \\
Serine & 2.27 & 2.55 & 2.44 & 2.51 & 2.35 \\
\hline Total of dispensable & 22.17 & 25.48 & 27.87 & 30.85 & 24.66 \\
\hline Total of amino acids & 37.41 & 42.30 & 49.64 & 54.64 & 43.15 \\
\hline
\end{tabular}

nd: not determined; a Soybean with low protein content and with hull; b Soybean with high protein content and with hull (Paucar-Menacho et al., 2010); c Conventional soybean with hull thermally treated $80^{\circ} \mathrm{C}$ for 20 minutes; d Soybean without LOX 2 and 3, hull-less, thermally treated $80^{\circ} \mathrm{C}$ for 20 minutes (Esteves et al., 2010); e Soybean with high protein content without LOXs, with hull, thermally treated $150{ }^{\circ} \mathrm{C}$ for 30 minutes (Andrade et al., 2010)

Table 17.3. Amino acids composition of conventional and genetically improved soybeans (g/100g)

$\beta$-Conglycinin is a trimer with a molecular weight (MW) of about $180 \mathrm{kDa}$. It is composed of 3 subunits, a $(63 \mathrm{kDa}), \alpha^{\prime}(67 \mathrm{kDa})$ and $\beta(48 \mathrm{kDa})$ (Apweiler et al., 2004; Liu, 1997; Nielsen, 1996). These subunits share a large degree of amino acid homologies. Furthermore, $\beta$ conglycinins with different subunit composition have also been identified. It is likely that the trimers are composed of randomly assembled mixture of subunits (Nielsen, 1996). Glycinin, on the other hand, is a hexamer with MW of about 320 to $375 \mathrm{kDa}$ and with 5 major subunits, G1, G2, G3, G4, and G5. Each subunit consists of 2 polypeptide chains, an acidic chain (about $40 \mathrm{kDa}$ ) and a basic chain (about $20 \mathrm{kDa}$ ), joined by a single intra-chain disulphide bond. G1, G2, and G3 can be grouped as they share about $90 \%$ sequence 
homologies. Similarity, G4 and G5 share about 90\% sequence homologies. However, sequence homologies between these 2 groups (G1, G2, G3 and G4, G5) are only about 50\% (Nielsen, 1996).

Whole soybean contains about $7-9 \%$ of protease inhibitors that are in the grain cotyledon (Brandon \& Friedman, 2002; Esteves et al., 2010; Penha et al., 2007). There are two types of inhibitors: the Kunitz trypsin (KTI), and trypsin inhibitor and chymotrypsin Browman-Birk (BBI) (Miura et al., 2005; Monteiro et al., 2004; Monteiro et al., 2003). Although cultivars without protease inhibitors already exist (Barros et al., 2008), heat treatment alone is able to inactivate them, improving its nutritional value (Miura et al., 2005). These compounds can be removed with heat treatment of the grain and genetic breeding, without prejudice the quality of protein (Andrade et al., 2010; Machado et al., 2008).

Lectins are widely distributed in plants and animals and are present in greater quantities in grain legumes and grasses. They are proteins that do not interact with the immune system, but are able to recognize specific sites on molecules and bind reversibly to carbohydrates without altering covalent structure of the glycosidic links of sites (Silva \& Silva, 2000). The lectins can interfere in the metabolism of animals and man. Some lectins, in contrast to other proteins, are resistant to enzymatic hydrolysis in the digestive tract and are recovered intact and still biologically active in animal feces. Since they are not inactivated by the action of enzymes of the digestive tract, these lectins can react with the gut epithelial cells causing complications to those who consume them. The lectins have the ability to bind to specific receptors in the intestinal epithelium, and this interaction interferes in the absorption and utilization of nutrients, causing poor performance in developing animals (Ritt, 2005). Soybean lectins are tetrameric protein with a molecular weight of $110-120 \mathrm{kDa}$ constituted by four subunits of $30 \mathrm{kDa}$ each. The natural content of lectin in soybean ranged from 2.10 to $5.68 \mathrm{mg} / \mathrm{g}$ (Gu et al., 2010; Paucar-Menacho et al., 2010), however this content can be reduced during the heat treatment. It has been observed that soybean thermally treated for 25 minutes showed no hemagglutinating activity and its analysis through sodium dodecyl sulfate polyacrylamide gel electrophoresis (SDS-PAGE) confirmed the absence of lectins. However, activities of trypsin inhibition and urease were detected (Machado et al., 2008). Thus, lectins demonstrated larger sensibility to heating than trypsin inhibitors and urease.

Some proteins, such as lipoxygenase and urease, have enzyme activity. Lipoxygenases (LOX 1,2 and 3) are enzymes belonging to a group of nonheme iron containing proteins widely distributed in soybean, representing up to $2 \%$ of soybean seed protein (Loiseau et al., 2001). They catalyze the oxidation of polyunsaturated fatty acids such as linoleic (18:2) and alinolenic (18:3) to produce unsaturated fatty acid hydroperoxides (Liavonchanka \& Feussner, 2006). Those hydroperoxides are further decomposed into volatile compounds such as hexanal aldehyde and other carbonyl compounds that are responsible for the beany flavors. With the genetic breeding, cultivars have been developed without lipoxygenase in order to decrease the production of beany flavor. The reduction of beany flavor also may occur in function of processing, since lipoxygenase is an enzyme thermolabile.

Urease is an enzyme thermolabile which correlates directly with levels of phytochemicals with antinutritional action presents in foods. Therefore, with the inactivation of the enzyme urease possibly some phytochemicals with anti-nutritional effect such as trypsin inhibitors and lipoxygenases, could be destroyed (Wiriyaumpaiwong et al., 2004). The analysis of urease is used as an indication that the thermal process was sufficient to inactivate phytochemicals with anti-nutritional effect present in soybean. The analysis of activity ureatic is a good indicator of adequate heat processing when it is between the cut points 
from 0.01 to 0.30 (Mendes, 2004; Runho, 2009). It has been demonstrated that two soybeans cultivars presented urease activity of 2.39 and 2.86, however, after subjected to 15 minutes in an autoclave, the urease activity in this cultivars was reduced to 0.10 and 0.12 (Machado et al., 2008).

\subsection{Other soybean components}

Soybean contains other compounds, among them isoflavones, oxalate, phytic acid and bioactive peptides, which act in different ways in the human body. Isoflavones are a subclass of a large group called flavonoids. Because of its estrogenic activity, are also known as phytoestrogens (Cederroth \& Nef, 2009). In soybean there are basically three types of isoflavones that are normally present in four different isoforms: glucosides (daidzin, genistin and glycitin); acetylglucosides (acetyldaidzin, acetylgenistin and acetylglycitin); malonylglucosides (malonyldadzin, malonylgenistin and malonylglycitin) and structure unconjugated aglycone (daidzein, genistein and glycitein) (Kao et al., 2007; Pereira \& Oliveira, 2002). Soybean is the main source of isoflavones (genistein, daidzein and glycitein), and its concentration range from 1.45 to $4.59 \mathrm{mg} / \mathrm{g}$ (Table 17.4) Traditional fermented products (miso, tempeh) contain high concentrations of aglycone forms, genistein and daidzein, resulting from the enzymatic action of $\beta$-glucosidase, while non-fermented products such as dried beans, aqueous extracts of soybeans, soy flour and tofu, contain high concentrations of the glucosides, genistin and daidzin (Wang \& Murphy, 1994).

The majority of species in the Leguminosae family contain oxalate in one or more of their tissues. The greater concentrations of oxalate in soybean are found in the mature seeds (Ilarslan et al., 2001; Nakata, 2003). The oxalate content of some plants is known to vary by genotype of soybean and possibly within cultivars under different growth conditions. Some Brazilian soybean cultivars, such as UFV-116 and OCEPAR-19 present oxalate content of 0.38 and $0.20 \mathrm{mg} / 100 \mathrm{~g}$, respectively (Esteves et al., 2010). Absorbed oxalate cannot be metabolized by humans and is excreted in the urine. In humans, high urinary oxalate increases the risk of calcium oxalate $(\mathrm{CaOx})$ kidney stones because $\mathrm{CaOx}$ is poorly soluble in the urine. Saturated oxalate in solution binds to Ca to form crystals that aggregate, often becoming large enough to block the urinary stream (Massey et al., 1993).

The phytic acid, also known as phytate, inositol hexaphosphate (IP6), myo-inositol, myoinositol and inositolphosfate, is the main form of phosphorus stocks in soybean who is essential for germination of the grain (Domínguez et al., 2002) (Table 17.5).

During processing, storage, fermentation, germination and digestion of grains and seeds, IP6 may be partly dephosphorylated to produce compounds as pentaphosphate (IP5), tetraphosfato $\left(\mathrm{IP}^{4}\right)$, triphosphate $\left(\mathrm{IP}^{3}\right)$ and possibly inositol diphosphate $\left(\mathrm{IP}^{2}\right)$ and monophosphate $\left(\mathrm{IP}^{1}\right)$, by action of endogenous phytases (Chiplonkar \& Agte, 2005; Domínguez et al., 2002) (Table 17.5). Only IP6 and IP5 exert a negative effect on the bioavailability of minerals. The other compounds formed such as $\mathrm{IP}^{4}$ and $\mathrm{IP}^{3}$ has low capacity to bind to the minerals or complexes formed are more soluble. Furthermore, these compounds may have antioxidant properties (Andrade et al., 2010; Domínguez et al., 2002; Martino et al., 2007).

During gastrointestinal digestion or food processing of proteins, small bioactive peptides can be released. Food-derived peptides commonly contain 2 to 9 amino acids (Kitts \& Weiler, 2003). However, this range may be extended to 20 or more amino acid units (Korhonen \& Pihlanto, 2003). Numerous biologically active peptides have been identified in foods, and may act as regulatory compounds with hormone-like activities. Soybean is a 
potential source of bioactive peptides which play an important role in physiological activities, particularly those related to the prevention of chronic diseases. Peptides with other biological activities, such as opioid agonistic and antagonistic, antioxidative, anticancer, and immunomodulatory actions have also been identified in soybean (Wang \& De Mejia, 2005).

\begin{tabular}{|c|c|c|c|c|c|c|}
\hline Types & Isoforms & BRS 133 a & BRS $258^{b}$ & OCEPAR-19 c & UFV-116 d & UFVTN 105AP e \\
\hline \multirow[t]{3}{*}{ Glucosides } & Daidzin & 424.6 & 147.1 & 237.5 & 74.5 & 308.6 \\
\hline & Genistin & 361.2 & 230.9 & 382.0 & 325.5 & 498.1 \\
\hline & Glycitin & 10.4 & 60.2 & 59.0 & 70.0 & 106.4 \\
\hline \multirow[t]{3}{*}{ Malonyl } & Daidzin & 131.6 & 575.6 & 211.0 & 59.5 & 395.1 \\
\hline & Genistin & 1007.5 & 729.6 & 263.0 & 213.5 & 526.2 \\
\hline & Glycitin & 419.6 & 226.4 & 27.5 & 33.0 & 38.5 \\
\hline \multirow[t]{3}{*}{ Acetyl } & Daidzin & $\mathrm{nf}$ & $\mathrm{nf}$ & 32.0 & $\mathrm{nf}$ & 227.8 \\
\hline & Genistin & $\mathrm{nf}$ & $\mathrm{nf}$ & 40.5 & 28.5 & 233.9 \\
\hline & Glycitin & $\mathrm{nf}$ & $\mathrm{nf}$ & $\mathrm{nf}$ & $\mathrm{nf}$ & 99.9 \\
\hline \multirow[t]{3}{*}{ Aglycones } & Daidzein & 109.8 & 76.9 & 112.0 & 26.5 & 143.3 \\
\hline & Genistein & 144 & 154.1 & 124 & 86.5 & 34.5 \\
\hline & Glycitein & 13.1 & 23.0 & 10.5 & $\mathrm{nf}$ & 9.1 \\
\hline \multicolumn{2}{|c|}{ Total Isoflavones } & 2621.8 & 2223.8 & 149.09 & 917.5 & 2621.4 \\
\hline
\end{tabular}

nf: not found; a Soybean with low protein content and with hull; b Soybean with high protein content and with hull (Paucar-Menacho et al., 2010); c Conventional soybean with hull thermally treated $80^{\circ} \mathrm{C}$ for 20 minutes; d Soybean without LOX 2 and 3, hull-less, thermally treated $80{ }^{\circ} \mathrm{C}$ for 20 minutes (Esteves et al., 2010); e Soybean with high protein content without LOXs, with hull, thermally treated $150^{\circ} \mathrm{C}$ for 30 minutes (Andrade et al., 2010)

Table 17.4. Isoflavone composition of conventional and genetically improved soybeans $(\mu \mathrm{g} / \mathrm{g})$.

\begin{tabular}{ccccc}
\hline Compounds & Embrapa 48 $^{\mathrm{a}}$ & BRS-213 $^{\mathrm{b}}$ & BRS-155 $^{\mathrm{c}}$ & UFVTN 105AP d $^{\text {BR }}$ \\
\hline Phytate & 0.78 & 1.75 & 1.40 & 1.11 \\
$I P^{6}$ & 0.62 & 1.01 & 0.82 & 0.67 \\
$I P^{5}$ & 0.12 & 0.43 & 0.43 & 0.27 \\
$I P^{4}$ & 0.04 & 0.23 & 0.12 & 0.12 \\
$I P^{3}$ & $\mathrm{nf}$ & 0.08 & 0.03 & 0.05 \\
\hline
\end{tabular}

nf: not found; a Conventional soybean with hull, with hull, thermally treated $150{ }^{\circ} \mathrm{C}$ for 30 minutes; $\mathrm{b}$ Soybean without LOXs, with hull, thermally treated $150{ }^{\circ} \mathrm{C}$ for 30 minutes; c Soybean with reduced trypsin inhibitor content, with hull, thermally treated $150{ }^{\circ} \mathrm{C}$ for 30 minutes; d Soybean with high protein content without LOXs, with hull, thermally treated $150^{\circ} \mathrm{C}$ for 30 minutes (Andrade et al., 2010)

Table 17.5. Phytate content of conventional and genetically improved soybeans (mg/100g). 


\subsection{Protein quality}

Protein content among studied soybean cultivars (commercial, triple zero, not without LOX and KTI, without LOX and KTI, with and without LOX KTI with LOX and KTI) varies from 31.32 to $44.07 \mathrm{~g} / 100 \mathrm{~g}$ (Ciabotti et al., 2006; Felix \& Canniatti-Brazaca, 2008; Martino et al., 2007; Mendes et al., 2007; Monteiro et al., 2004; Oliveira et al., 2007; Silva et al., 2006; Toledo et al., 2007). The biological utilization of soy protein is lower than that animal protein due to limitations in some essential amino acids and the presence of phytochemicals with antinutritional effects such as protease inhibitors (KTI and BBI) (Monteiro et al., 2004; Wang et al., 2000). These compounds inhibit the proteolytic enzymes and, consequently, reduce protein digestion leading to a decrease in weight gain and growth of animals (Miura et al., 2005; Monteiro et al., 2004). However, these compounds are thermolabile and can be inactivated by heat treatment.

With genetic breeding, new cultivars of soybean have been developed without KTI, lectins and lipoxygenase to improve their protein quality and flavor, making them more suitable for human consumption. Heat treatment is also a determinant of protein quality since it can change the structure of compounds with effect anti-nutritional in conventional soybean cultivars and thus inhibit their negative nutritional effect by increasing protein digestibility. Some animal studies demonstrated that conventional soybean cultivars or genetically improved heat treated soybean showed values of Relative Protein Efficient Ration (R-PER) ranging from 30 to 77 and Relative Digestibility True (R-DV) from 82 to 90 (Carvalho, 2009; Monteiro et al., 2004). These variations in protein quality are related to genetic breeding of cultivars and processing, including heat output, binomial time: temperature, and peeling. In vivo studies showed that heat treatment of grains reduced the activity of trypsin inhibitor, urease and did not affect protein solubility (Andrade et al., 2010; Carvalho, 2009). In these studies, soybean with hulls presented higher nutritional quality, indicating that soy can be used in integral form as a source of quality protein, and in addition contributing to improving the intake of dietary fiber and minerals.

The soybean breeding programs have concentrated on developing more productive cultivars, and more recently, there is also a concern with quality characteristics such as content and composition of storage protein. These new cultivars need to be characterized from the nutritional point of view (Gonçalves et al., 2007), because the use of vegetable proteins influences the processing of the product, its amino acid profile and the presence of phytochemicals with potential anti-nutritional effect.

\subsection{Mineral bioavailability}

Besides the evaluation of protein quality, it is also of great importance the study of mineral content and its bioavailability in different soybean cultivars (Table 17.6). In the five cultivars presented in the following table, it stands out they contain relevant levels of calcium, iron and zinc, whose intake is marginal for some population groups in social vulnerability. It appears that the contents of some minerals, especially the so-called antioxidants, have not yet been quantified.

A comparative study of two genetically improved soybean cultivars (without LOX2 and LOX3) and a conventional cultivar, using an animal model and radioactive markers, revealed a lower iron and zinc bioavailability in the improved cultivar likely due to higher phytate content (Martino et al., 2007). However, in a study of a new cultivar, without lipoxygenase, a lower concentration of phytate and phytate:iron molar ratio and high protein content, using an animal model of depletion and repletion of hemoglobin, 
demonstrated that the Relative Biological Values of hull and hull-less soybean flour were approximately 68\% (Carvalho, 2009). These studies demonstrate the importance of combining the grain processing with the genetic breeding to promote the bioavailability of minerals. Stands out that soybean hull flours resulted in a good source of dietary fiber allowing elimination the initial hulling step in the industrial processing of soybean flour.

\begin{tabular}{cccccc}
\hline Minerals & BRS 133 a & BRS 258 $^{\mathbf{b}}$ & OCEPAR-19 $\mathrm{c}^{\text {OCF }}$ & UFV-116 $\mathrm{d}^{\text {UFVTN 105AP } \mathrm{e}}$ \\
\hline $\mathrm{Ca}$ & 290.4 & 335.4 & 208.0 & 171.0 & 177.9 \\
$\mathrm{Fe}$ & 22.3 & 26.3 & 40.0 & 40.0 & nd \\
$\mathrm{Zn}$ & 7.4 & 8.3 & nd & nd & nd \\
$\mathrm{K}$ & nd & nd & 1880.0 & 1740.1 & 1925.6 \\
$\mathrm{Na}$ & nd & nd & 2.4 & 2.5 & 3.2 \\
$\mathrm{P}$ & 524.4 & 1.2 & nd & nd & nd \\
$\mathrm{Mg}$ & nd & nd & 317.0 & 261.0 & 282.4 \\
$\mathrm{Cu}$ & 2.88 & 3.14 & nd & nd & nd \\
\hline
\end{tabular}

nd: not determined; a Soybean with low protein content and with hull; b Soybean with high protein content and with hull (Paucar-Menacho et al., 2010); c Conventional soybean with hull thermally treated $80^{\circ} \mathrm{C}$ for 20 minutes; d Soybean without LOX 2 and 3, hull-less, thermally treated $80^{\circ} \mathrm{C}$ for 20 minutes (Esteves et al., 2010); e Soybean with high protein content without LOXs, with hull, thermally treated $150{ }^{\circ} \mathrm{C}$ for 30 minutes (Andrade et al., 2010)

Table 17.6. Mineral content of conventional and genetically improved soybeans (mg/100g in dry basis)

The heat treatment of soybean by removing the peel after soaking improved the availability of iron in vitro (Felix \& Canniatti-Brazaca, 2008). A study using the femur ${ }^{45} \mathrm{Ca}$ uptake method, showed similar calcium bioavailability between genetically breed (without LOX $2 \mathrm{e}$ LOX 3 ) and conventional cultivars thermally treated $\left(80^{\circ} \mathrm{C}\right.$ for 20 minutes). In these study, the higher oxalate:calcium molar ratio and the higher content of oxalate and phytate in the improved cultivar did not affect calcium absorption (Martino et al., 2008). These observations are very important for individuals and populations that use soy diets since they demonstrate that the adequate heat treatment could be a good strategy for improving the minerals bioavailability of soybean. Also, the use of whole soybean, including the hull, is a good strategy to increase dietary fiber consumption in the human diet without impairing iron bioavailability.

\section{Studies on functional properties of soybean}

A food is defined as functional if, "in addition to providing nutrients, it contains bioactive compounds that act promoting health and/or reducing the risk of chronic diseases" (Diplock et al., 1999). In this context, soybean is considered a functional food with high potential. Experimental and epidemiological studies have provided evidence for a variety of health benefits derived from the consumption of soybean and soy food products.

\subsection{Improvement in serum lipid profile}

The consumption of soybean or its bioactive compounds has been reported to contribute significantly to reducing cholesterol and triglyceride levels in laboratory animals and humans (Esteves et al., 2011; Reynolds et al., 2006; Sirtori et al., 2007; Sirtori et al., 2009). The 
beneficial effect on lipemia has been explained by the action of various constituents present in soybean which act via different mechanisms:

Amino acid protein profile. The high content of arginine and low methionine content (Wilson et al., 2007) can promote higher levels of nitric oxide (Gornik \& Creager, 2004) and lower levels of homocysteine (Torres et al., 2006), favoring vessel relaxation and reduction of the risk of cardiovascular disease. There are suggestions that soy protein exerts hypolipidemic and antiatherogenic effects because the relationship between amino acids lysine/arginine alters the relationship insulin/glucagon which, when elevated, increases the risk of cardiovascular disease (Demonty et al., 2002; Torres et al., 2006).

Action of non-digestible peptides. The presence of peptides from soybean not digested in the gastrointestinal tract, has also explained their hypocholesterolemic effect. Peptides increase the fecal excretion of steroids, elevating both the hepatic synthesis of bile acids and receptors of LDL-c, as well as the uptake and oxidation of cholesterol in the liver (Belleville, 2002). Hypocholesterolemic effect has been found in peptide Leu-Pro-Tyr-Pro-Arg, a protein fragment derived from soybean glycinin, which reduced serum cholesterol in mice $(-25.4 \%$ in total cholesterol and $-30.6 \%$ in LDL-c) (Yoshikawa et al., 2000). This peptide has structural homology to enterostatin (Val-Pro-Asp-Pro-Arg). Although both have hypocholesterolemic activities, enterostatin did not increased excretion of bile acids in feces, suggesting that they may act by different mechanisms (Takenaka et al., 2004).

Bioactivity of isoflavones. Isoflavones, acting on the $\beta$-estrogen receptors present in the liver, lead to increased number of hepatic receptors of LDL-c, and favors the catabolism of cholesterol and $\beta$-oxidation of fatty acids (Dewell et al., 2002; Douglas et al., 2006; Torrezan et al., 2008). The antioxidant effect of isoflavones can act protecting the oxidation of copperdependent LDL-c and favor a serum lipid profile associated with protection against atherosclerosis (Teixeira Damasceno et al., 2007).

Hypolipidemic action of storage proteins. $\beta$-conglycinin and glycinin showed hypolipidemic effect, through increased fecal excretion of fatty acid, induction of $\beta$-oxidation in the liver and decreased hepatic synthesis of fatty acids by down regulation of fatty acid synthesis and up regulation of liver VLDL receptors (Duranti et al., 2004; Fukui et al., 2004; Moriyama et al., 2004).

Hypolipidemic action of phytate. The phytate intake improves the serum lipid profile and reduces the hepatic lipid deposition in animal model of atherosclerosis (Lee et al., 2007). It is known that phytate exerts effect on hepatic glucose-regulating enzyme activities and reduce the risk of high fat diet-induced hyperglycemia (S.M. Kim et al., 2010).

The evidences commented above show that the beneficial effects of soybean on lipid profile improvement is mediated by various constituents present in the grain and thus the intake of whole soybean has potential to exert greater effect in comparison with supplementation of their components. This idea is supported by some evidence.

The hypocholesterolemic effect of soy consumption may be attributed not only to the presence of bioactive compounds (intrinsic effect) but also to replacing animal foods rich in saturated fat and cholesterol (extrinsic effect). A recent study estimated the intrinsic and extrinsic effects of soybean to reduce cholesterol and verified that the combined effects are important to reduce cholesterol in approximately $4 \%$ (Jenkins et al., 2010). In fact, the synergistic action of amino acids and isoflavones in improving lipid metabolism and activation of the LDL-c has been demonstrated (Bertipaglia de Santana et al., 2008). 
A study performed with a group of postmenopausal women found no significant hypocholesterolemic effect of consuming soy milk for 4 weeks, despite good adherence of the participants (Beavers et al., 2010). The authors discussed that the baseline cholesterol status, supplement type, dosage, and duration, as well as dietary control, are all potential confounding factors that have been identified as determinants of the conflicting results.

\subsection{Protection against oxidative stress}

Isoflavones and its metabolites formed by bacterial action in the intestinal lumen, have structural determinants to exert strong antioxidant activity (Arora et al., 1998). Studies in humans have shown that the antioxidant effect of soy products. The intake for 2 weeks, of soy bars containing 7 and 12 milligrams of daidzein and genistein, respectively, increased the resistance of oxidation of isolated LDL (Tikkanen et al., 1998), although the ingestion of a product isolated soy containing protein and isoflavones did not show antioxidant effects of plasma and LDL-c (Steinberg et al., 2003). The antioxidant effects are mediated by direct elimination of free oxygen radicals by isoflavones (Teixeira Damasceno et al., 2007) and by increasing the concentrations of antioxidant enzymes, improving the body's antioxidant defense (Engelman et al., 2005; Rios et al., 2008). It is believed that a diet rich in isoflavones causes LDL-c to become resistant to peroxidation, that is responsible for the generation of a cascade of events that produces atherosclerotic plaques, making the consumption of soy a protective factor against atherosclerosis (Mateos-Aparicio et al., 2008; Sacks et al., 2006).

Several amino acids that composed bioactive peptides, such as Tyr, Met, His, Lys, and Trp, have antioxidant properties. Saito et al. (2003) evaluated 108 peptides containing either 2 His or Tyr residues and 114 peptides structurally related to Pro-His-His. They observed that the tripeptides containing Trp or Tyr residues at the C-terminus had strong radical scavenging activities, but very weak peroxynitrite scavenging activity. They also found that the antioxidative peptides may exert strong synergistic effects with some other antioxidants, such as phenolic compounds.

Phytates present in soybeans also have a positive effect on health, exerting a protective action against oxidative stress (Lee et al., 2007; Martinez Dominguez et al., 2002). Phytate binds to iron, suppressing the catalysis of this ion in oxidative reactions, which favors the preservation of the seed. Through this mechanism, there is inhibition of lipid peroxidation and consequent acceleration of the autoxidation of ferrous ions to ferric ions, with the formation of ferric chelates (Quirrenbach et al., 2009).

It is known that the protective effect of soybean against oxidative stress involves the action of several bioactives compounds and once again, it is reasonable to state that soy intake may offer greater antioxidant protection mediated by the synergistic effect of several components: isoflavones and their metabolites generated in the intestinal lumen, peptides and phytic acid. In addition, the action of other antioxidants such as vitamin $\mathrm{E}$ and minerals like copper, iron, zinc and manganese, although not present in high concentrations in soybean, help in the antioxidant protection of the body. All these factors suggest that eating whole soybean would be more effective than the intake of their isolated components.

\subsection{Effect on glycemic control}

Soybean has shown a potential to exert physiological effects through mechanisms that stimulate insulin production and decrease the glycemic index of diet, suggesting the possibility of their health claim to act in the prevention and control of diabetes and obesity and its metabolic complications. 
The effect of isoflavones in reducing blood glucose may be explained by the stimulus by genistein to pancreatic $\beta$ cells which increases insulin production and consequently also the glucose uptake by cells (Esteves et al., 2011). These effect has been demonstrated in studies with animals that received genistein (Jonas et al., 1995) and also in a in vitro study, which used adipocytes and insulinoma cells, showing that bioactive compounds formed from isoflavonoids and soy peptides during the fermentation process to produce meju, activated signaling cascades that stimulated insulin release (Kwon et al., 2011).

The dietary fiber contained in soybeans is effective in controlling blood glucose (Penha et al., 2007). It can reduce the rate of emptying of the digestive tract, increase the rate of peristalsis of the bowel and slow down the rate of glucose uptake and therefore its importance in the control of blood glucose (Takahashi et al., 2003). In a clinical study, the intake of soybean fiber resulted in decreased the blood glucose levels after ingestion of a glucose solution. Thus, soy fibers may adsorb glucose in the intestine and slow their release for absorption (Messina et al., 1992). A cake made with whole soybean flour showed low glucose and insulin indexes in study with a group of 20 individuals (Oku et al., 2009).

Phytate also shows potential in controlling diabetes, as demonstrated by its hypoglycemic effect in diabetic mice (S.M. Kim et al., 2010; Lee et al., 2007). Lee (2006) observed that consumption of diets containing phytate reduced the high blood glucose levels and glycated hemoglobin in diabetic mice.

In summary, various bioactive soy compounds may act on mechanisms that improve the metabolism of carbohydrates, working in reducing the risk of diabetes and metabolic complications of obesity. As an adjunct to control diabetes, it stands out the importance of dietary fiber to improve the glycemic index of diet as well as the antioxidant components to minimize the oxidative stress that is present in this disease. However, in diabetic individuals, studies are needed to prove whether pancreatic $\beta$ cells of these individuals are responsive to stimulation of soy isoflavones to increase insulin release.

\subsection{Antihypertensive effects and protection of the endothelium}

Antihypertensive soybean peptides are the most extensively studied. Peptides as Tyr-ValVal-Phe-Lys, Pro-Asn-Asn-Lys-Pro-Phe-Gln, Asn-Trp-Gly-Pro-Leu-Val, Ile-Pro-Pro-Gly-ValPro-Tyr-Trp-Thr, Thr-Pro-Arg-Val-Phe, Ile-Ala, Tyr-Leu-Ala-Gly-Asn-Gln, Phe-Phe-Leu, and Ile-Tyr-Leu-Leu show their activity by inhibiting angiotensin-converting enzyme-ACE, which is a nonspecific dipeptidyl carboxypeptidase associated with the regulation of blood pressure by modulating the rennin-angiotensin system (Chen et al., 2004).

Some peptides such Val-Pro-Pro and Ile-Pro-Pro, released during the fermentation of soybean meal, added of casein to produce of miso, showed hypertensive action by inhibiting ACE (Inoue et al., 2009).

Black soybean extract showed potent inhibitory activity of the platelet aggregation induced by a collagen in vitro model, using platelets isolated from humans (K. Kim et al., 2010).

Animal studies suggest that soybean may exert a protective effect against cardiovascular disease when the fetus is exposed to isoflavones via maternal diet (Bonacasa et al., 2011).

\subsection{Chemopreventive effects}

Epidemiologic studies have demonstrated the direct association between the protection of breast cancer and soy intake (Dong \& Qin, 2011). This effect has been attributed to the bioactivity of isoflavones and their estrogenic effect. However, intervention studies do not always demonstrate benefits of supplementation of isolated soy isoflavones in reducing the 
risk of breast cancer. In a study with 406 premenopausal women, who received 80 or 120 $\mathrm{mg}$ /day of isoflavones or placebo, during two years, did not showed modification in mammographic density, which is a marker of risk of breast cancer. However, there was a significant reduction of the marker over time (Maskarinec et al., 2009). There is evidence that early exposure to the bioactive compounds of soybean, via maternal diet, may alter the paracrine signaling in adipocytes of breast tissue and increase the differentiation of epithelial tissue, with implications in prevention of breast cancer associated with obesity (Su et al., 2009).

In prostate cancer, the chemopreventive effect of the soybean mediated by mechanisms of modulations of gene expression was evidenced in a study in which isoflavones derived from soybean cake exhibited antiproliferative effects on prostate cancer cells, decreasing the expression of cyclin B1 (Wang et al., 2009). A recent study investigated the effect of administration of soy isoflavones as an adjunct in hormone therapy and verified that for postmenopausal women there was lower risk of cancer recurrence, for a monitoring period of 5.1 years (Kang et al., 2010).

Although components of soybean have demonstrated potential to act as antiproliferative agents, their effect in reducing cancer risk is still controversial. It is possible that the metabolic imprint is the main mechanism to explain the inverse association between cancer and soy intake. In fact, it was found that for breast cancer, the association is present for the Asian population and not for the western population (Dong \& Qin, 2011). For this reason, the habit of soy intake by the population through successive generations could be a useful strategy to obtain the chemopreventive benefits of the bioactive compounds in soybeans.

\subsection{Effects on obesity and metabolic syndrome}

Several anorectic peptides have been already identified to exert antiobesity activity through decreasing food intake, fat and lean body mass, and body weight (Challis et al., 2004). For example, Leu-Pro-Tyr-Pro-Arg, a peptide from soybean glycinin A5A4B3 subunit (Takenaka et al., 2004) and Pro-Gly-Pro have been found to have anorectic activities.

The consumption of soy protein may also lead to low hepatic deposits of triglycerides (Ascencio et al., 2004), reducing the risk of hepatic lipotoxicity and therefore of steatosis (Tovar et al., 2005). In animals, soybean protein modulated the expression of genes that regulated lipid metabolism and thyroid hormone, promoting weight loss (Simmen et al., 2010). These mechanisms of action may attenuate metabolic changes that occur in obesity, which are related to insulin resistance (Oh et al., 2011).

Soy protein isolate was found to lower plasma triglycerides, increase adiponectin (Nagasawa et al., 2003), accelerate lipid metabolism, and decrease body fat in obese rats and mice (Aoyama et al., 2000).

Thus, there is enough scientific evidence to motivate soybean research for exploring their potential for its use as a coadjuvant in the treatment of obesity and its complications.

\subsection{Other diverse effects}

Soybean peptides with immunomodulatory activities have also been identified from soybean protein hydrolysates. For example, immunostimulating peptide preventing the alopecia induced by cancer chemotherapy has been isolated from an enzymatic digest of soybean protein (Tsuruki et al., 2005; Tsuruki \& Yoshikawa, 2004). Recently, it was shown that a lectin of $48-\mathrm{kDa}$ purified soybean black Koreana inhibited the activity of reverse transcriptase of HIV-I with an IC (50) of 1.38 micromolar (Fei Fang et al., 2010). 
Although there are suggestions of the benefits of soy on bone health, clinical studies do not always prove such effects (Alekel et al., 2010; Kenny et al., 2009). A prospective cohort study of the Chinese population showed that the intake of soybean and its products was associated with protection against hip fracture in women but no association in men (Koh et al., 2009). There are doubts if the intake of soybean can provide superior beneficial effect on bone health (Reinwald \& Weaver, 2010).

Prebiotic effect with improvement in the balance of minerals especially calcium and magnesium was demonstrated in rats, which consumed the $120 \mathrm{mg} /$ day/animal of galactooligossacarides contained in soybean serum obtained from by-product of the manufacturing of tofu (Tenorio et al., 2010).

Soy isoflavones derived from soybean cake exhibited effect in inhibiting apoptosis and inflammation induced by UVB in in vitro and in vivo mice models, suggesting bioactivity of soy components against aging (Chiu et al., 2009).

In animal models of neurotoxicity induced by beta-amyloid, neuroprotective effect of soy isoflavones were demonstrated, indicating the possible benefit of bioactive compounds as co adjuvant in disease (Ma et al., 2009).

The benefits of soy isoflavones as an alternative to estrogen therapy for the treatment of menopausal symptoms are still uncertain (Steinberg et al., 2010). A recent review on the subject states that the number of studies is limited to assess the effectiveness of soy foods in alleviating vasomotor and urogenital symptoms (Levis \& Griebeler, 2010). Study on animals showed that the soybean extract rich in isoflavones increased the epithelium and vaginal collagen (Carbonel et al., 2011).

\section{Conclusion}

Soybean is a legume with great potential for use as human food, offering especially protein, lipids, fiber, minerals and bioactive compounds. Studies have shown their nutritional value and health properties, with potential of reducing the risk of non-communicable diseases. Many studies focus on the use of isolated soy constituents, especially isoflavones, bioactive peptides and protein. Therefore, it is necessary to intensify research that allows the use of whole soybeans for the supply of nutrients and bioactive compounds and to evaluate the synergistic effect of these. Studies with different processing techniques should continue, since they can optimize the nutritional and functional quality of conventional soybeans or genetically improved varieties.

Health policy in Western countries should be implemented to encourage increased consumption of whole soybean, such as a partial substitute for refined ingredients.

\section{References}

Alekel, D. L., Van Loan, M. D., Koehler, K. J., Hanson, L. N., Stewart, J. W., Hanson, K. B., Kurzer, M. S., \& Peterson, C. T. (2010). The Soy Isoflavones for Reducing Bone Loss (SIRBL) Study: a 3-y randomized controlled trial in postmenopausal women. The American Journal of Clinical Nutrition, Vol.91, No.1, (January 1, 2010), pp.218-230

Andrade, G. F. (2010). Efeito da ingestão de farinha integral de soja de elevado teor protéico sobre fatores de risco de doenças crônicas não transmissíveis. Departamento de Nutrição e Saúde. Viçosa: Universidade Federal de Viçosa. 
Andrade, G. F., Dantas, M. I. S., Piovesan, N. D., Barros, E. G., Costa, N. M. B., \& Martino, H. S. D. (2010). Tratamento térmico adequado proporciona melhoria da qualidade nutricional de farinhas de soja elaboradas a partir de novos cultivares destinados à alimentação humana. Revista Instituto Adolfo Lutz, Vol.69, No.4, pp.541-548

Aoyama, T., Fukui, K., Nakamori, T., Hashimoto, Y., Yamamoto, T., Takamatsu, K., \& Sugano, M. (2000). Effect of Soy and Milk Whey Protein Isolates and Their Hydrolysates on Weight Reduction in Genetically Obese Mice. Bioscience, Biotechnology, and Biochemistry, Vol.64, No.12, pp.2594-2600

Apweiler, R., Bairoch, A., Wu, C. H., Barker, W. C., Boeckmann, B., Ferro, S., Gasteiger, E., Huang, H., Lopez, R., Magrane, M., Martin, M. J., Natale, D. A., O'Donovan, C., Redaschi, N., \& Yeh, L. S. L. (2004). UniProt: the Universal Protein knowledgebase. Nucleic Acids Research, Vol.32, No.suppl 1, (January 1, 2004), pp.115-119

Arora, A., Nair, M. G., \& Strasburg, G. M. (1998). Antioxidant Activities of Isoflavones and Their Biological Metabolites in a Liposomal System. Archives of Biochemistry and Biophysics, Vol.356, No.2, pp.133-141

Ascencio, C., Torres, N., Isoard-Acosta, F., Gímez-Pérez, F. J., Hernández-Pando, R., \& Tovar, A. R. (2004). Soy Protein Affects Serum Insulin and Hepatic SREBP-1 mRNA and Reduces Fatty Liver in Rats. The Journal of Nutrition, Vol.134, No.3, (March 1, 2004), pp.522-529

Barros, J. G. A., De Moraes, R. M. A., Piovesan, N. D., De Barros, E. G., \& Moreira, M. A. (2008). Efeito do inibidor de protease Kunitz sobre níveis de lipoxigenases em semente de soja. Ciência e Agrotecnologia, Vol.32, pp.1126-1132

Baumgartner, R. M., Fehr, W. R., Wang, T., \& Wang, G. (2010). Tocopherol Content of Soybean Lines with Mid-oleate and 1\%-Linolenate. Crop Science, Vol.50, pp.770-774

Beavers, K. M., Serra, M. C., Beavers, D. P., Cooke, M. B., \& Willoughby, D. S. (2010). Soy and the exercise-induced inflammatory response in postmenopausal women. Applied Physiology, Nutrition, and Metabolism, Vol.35, pp.261-269

Belleville, J. (2002). Hypocholesterolemic effect of soy protein. Nutrition, Vol.18, No.7-8, pp.684-686

Bertipaglia de Santana, M., Mandarino, M. G., Cardoso, J. R., Dichi, I., Dichi, J. B., Camargo, A. E. I., Fabris, B. A., Rodrigues, R. J., Fatel, E. C. S., Nixdorf, S. L., Simão, A. N. C., Cecchini, R., \& Barbosa, D. S. (2008). Association between soy and green tea (Camellia sinensis) diminishes hypercholesterolemia and increases total plasma antioxidant potential in dyslipidemic subjects. Nutrition (Burbank, Los Angeles County, Calif.), Vol.24, No.6, pp.562-568

Bonacasa, B., Siow, R. C. M., \& Mann, G. E. (2011). Impact of Dietary Soy Isoflavones in Pregnancy on Fetal Programing of Endothelial Function in Offspring. Microcirculation, Vol.In press,

Boneti, L. P. (1981). Distribuição da soja no mundo. In: A soja no Brasil, S. Miyasaka, \& J. C. Medina, (pp. 1-16). Instituto de Tecnologia de Alimentos, Campinas.

Brandon, D. L., \& Friedman, M. (2002). Immunoassays of soy proteins. Journal of Agricultural and Food Chemistry, Vol.50, No.22, (oct 23), pp.6635-6642

Carbonel, A. A. F., Baracat, M. C. P., Simões, R. S., Simões, M. J., Baracat, E. C., \& Soares, J. M. J. (2011). The soybean concentrated extract proliferates the vagina of adult rats. Menopause, Vol.18, No.1, pp.93-101 
Caruso, M., \& Demonte, A. (2005). Histomorphometry of the small intestine of rats submitted to different proteic sources. Alim. Nutr, Vol.16, No.2, pp.131-136

Carvalho, A. W. (2009). Biodisponibilidade de ferro e qualidade proteica do cultivar de soja UFVTN 105AP com elevado teor proteico. Deparamento de Nutrição e Saúde. Viçosa: Universidade Federal de Viçosa.

Carvalho, A. W., Silva, C. O., Dantas, M. I. S., Natal, D. I. G., Ribeiro, S. M. R., Costa, N. M. B., \& Martino, H. S. D. (2011). The use hull soybean flour of heat-treated grains does not affect iron bioavailability in rats. Archivos Latinoamericanos de Nutrición, Vol.in press,

Cederroth, C. R., \& Nef, S. (2009). Soy, phytoestrogens and metabolism: A review. Molecular and Cellular Endocrinology, Vol.304, No.1-2, pp.30-42

Challis, B. G., Coll, A. P., Yeo, G. S. H., Pinnock, S. B., Dickson, S. L., Thresher, R. R., Dixon, J., Zahn, D., Rochford, J. J., White, A., Oliver, R. L., Millington, G., Aparicio, S. A., Colledge, W. H., Russ, A. P., Carlton, M. B., \& O'Rahilly, S. (2004). Mice lacking pro-opiomelanocortin are sensitive to high-fat feeding but respond normally to the acute anorectic effects of peptide-YY3-36. Proceedings of the National Academy of Sciences of the United States of America, Vol.101, No.13, (March 30, 2004), pp.46954700

Chen, J. R., Yang, S. C., Suetsuna, K., \& Chao, J. C. J. (2004). Soybean protein-derived hydrolysate affects blood pressure in spontaneously hypertensive rats. Journal of Food Biochemistry, Vol.28, No.1, pp.61-73

Chiplonkar, S., \& Agte, V. (2005). Predicting Bioavailable Zinc from Lower Phytate Forms, Folic Acid and Their Interactions with Zinc in Vegetarian Meals. Journal of the American College of Nutrition, Vol.25, pp.26-33

Chiu, T. M., Huang, C. C., Lin, T. J., Fang, J. Y., Wu, N. L., \& Hung, C.-F. (2009). In vitro and in vivo anti-photoaging effects of an isoflavone extract from soybean cake. Journal of Ethnopharmacology, Vol.126, No.1, pp.108-113

Ciabotti, S., Barcellos, M. F. P., Mandarino, J. M. G., \& Tarone, A. G. (2006). Avaliações químicas e bioquímicas dos grãos, extratos e tofus de soja comum e de soja livre de lipoxigenase. Ciência e Agrotecnologia, Vol.30, pp.920-929

Dantas, M. I. S., Andrade, G. F., Piovesan, N. D., \& Martino, H. S. D. (2009). Farinhas mistas de trigo e de soja agregam valor nutricional e sensorial em pães. Rev. Inst. Adolfo Lutz, Vol.68, No.2, (maio-ago), pp.209-214

Dantas, M. I. S., Silva, M. G., Pinto, C. R. R., Santos, P. C. A., Minim, V. P. R., \& Bittencourt, M. C. B. (2010). Farinhas de soja sem lipoxigenase agregam valor sensorial em bolos. Revista Ceres, Vol.57, No.2, (mar/abr), pp.141-144

Demonty, I., Lamarche, B., Deshaies, Y., \& Jacques, H. (2002). Role of soy isoflavones in the hypotriglyceridemic effect of soy protein in the rat. The Journal of Nutritional Biochemistry, Vol.13, No.11, pp.671-677

Dewell, A., Hollenbeck, C. B., \& Bruce, B. (2002). The Effects of Soy-Derived Phytoestrogens on Serum Lipids and Lipoproteins in Moderately Hypercholesterolemic Postmenopausal Women. J Clin Endocrinol Metab, Vol.87, No.1, (January 1, 2002), pp.118-121

Diplock, A. T., Aggett, P., Ashwell, M., Bornet, F., Fern, E. B., \& Roberfroid, M. B. (1999). Scientific concepts of functional foods in Europe: consensus document. . British Journal of Nutrition, Vol.81, pp.1-27 
Domínguez, B. M., Gómez, M. V. I., \& León, F. R. (2002). Acido fítico: aspectos nutricionales e implicaciones analíticas. ALAN, Vol.52, (set),

Dong, J. Y., \& Qin, L. Q. (2011). Soy isoflavones consumption and risk of breast cancer incidence or recurrence: a meta-analysis of prospective studies. Breast Cancer Research and Treatment, Vol.125, No.2, pp.315-323

Douglas, G., Armitage, J. A., Taylor, P. D., Lawson, J. R., Mann, G. E., \& Poston, L. (2006). Cardiovascular consequences of life-long exposure to dietary isoflavones in the rat. The Journal of Physiology, Vol.571, No.2, pp.477-487

Duranti, M., Lovati, M. R., Dani, V., Barbiroli, A., Scarafoni, A., Castiglioni, S., Ponzone, C., \& Morazzoni, P. (2004). The alpha' Subunit from Soybean 7S Globulin Lowers Plasma Lipids and Upregulates Liver Beta-VLDL Receptors in Rats Fed a Hypercholesterolemic Diet. The Journal of Nutrition, Vol.134, No.6, (June 1, 2004), pp.1334-1339

Engelman, H. M., Alekel, D. L., Hanson, L. N., Kanthasamy, A. G., \& Reddy, M. B. (2005). Blood lipid and oxidative stress responses to soy protein with isoflavones and phytic acid in postmenopausal women. Am J Clin Nutr, Vol.81, No.3, (Mar), pp.590596

Esteves, E. A., Bressan, J., Costa, N. M. B., Martino, H. S. D., Donkin, S. S., \& Story, J. A. (2011). Modified soybean affects cholesterol metabolism in rats similarly to a commercial cultivar. Journal of Medicinal Food, Vol.in press,

Esteves, E. A., Martino, H. S. D., Oliveira, F. C. E., Bressan, J., \& Costa, N. M. B. (2010). Chemical composition of a soybean cultivar lacking lipoxygenases (LOX2 and LOX3). Food Chemistry, Vol.122, No.1, pp.238-242

FAO/WHO. (2007). Food and Agriculture Organization. Protein and amino acid requirements in human nitrition. In: W. F. U. E. Consultation, (p. 265). Geneva, Switzerland: WHO/ FAO.

Fei Fang, E., Ho Wong, J., Lin, P., \& Bun Ng, T. (2010). Biochemical and Functional Properties of a Lectin Purified from Korean Large Black Soybeans A Cultivar of Glycine Max. Protein and Peptide Letters, Vol.17, pp.690-698

Felix, M. A., \& Canniatti-Brazaca, S. G. (2008). Disponibilidade de ferro in vitro de grãos de soja tostados por diferentes tratamentos. Ciência e Tecnologia de Alimentos, Vol.28, pp.78-83

Fukui, K., Kojima, M., Tachibana, N., Kohno, M., Takamatsu, K., Hirotsuka, M., \& Kito, M. (2004). Effects of Soybean Beta-Conglycinin on Hepatic Lipid Metabolism and Fecal Lipid Excretion in Normal Adult Rats. Bioscience, Biotechnology, and Biochemistry, Vol.68, No.5, pp.1153-1155

Gonçalves, C. A., Soares, N. S., Bolina, C. O., \& Barros, E. G. (2007). Influência da Temperatura no Acúmulo de Proteínas em Sementes de Soja. Revista Brasileira de Biociências, Vol.5, pp.1038-1040

Gornik, H. L., \& Creager, M. A. (2004). Arginine and Endothelial and Vascular Health. The Journal of Nutrition, Vol.134, No.10, (October 1, 2004), pp.2880-2887

Gu, C., Pan, H., Sun, Z., \& Qin, G. (2010). Effect of Soybean Variety on Anti-Nutritional Factors Content, and Growth Performance and Nutrients Metabolism in Rat. International Journal of Molecular Sciences, Vol.11, No.3, pp.1048-1056

Ilarslan, H., Palmer, R. G., \& Horner, H. T. (2001). Calcium Oxalate Crystals in Developing Seeds of Soybean. Annals of Botany, Vol.88, No.2, (August 1, 2001), pp.243-257 
Inoue, K., Gotou, T., Kitajima, H., Mizuno, S., Nakazawa, T., \& Yamamoto, N. (2009). Release of antihypertensive peptides in miso paste during its fermentation, by the addition of casein. Journal of Bioscience and Bioengineering, Vol.108, No.2, pp.111-115

Jenkins, D. J. A., Mirrahimi, A., Srichaikul, K., Berryman, C. E., Wang, L., Carleton, A., Abdulnour, S., Sievenpiper, J. L., Kendall, C. W. C., \& Kris-Etherton, P. M. (2010). Soy Protein Reduces Serum Cholesterol by Both Intrinsic and Food Displacement Mechanisms. The Journal of Nutrition, Vol.140, No.12, (December 1, 2010), pp.23022311

Jonas, J. C., Plant, T. D., Gilon, P., Detimary, P., Nenquin, M., \& Henquin, J. C. (1995). Multiple effects and stimulation of insulin secretion by the tyrosine kinase inhibitor genistein in normal mouse islets. Br J Pharmacol., Vol.114, No.4, pp.872-880

Kang, X., Zhang, Q., Wang, S., Huang, X., \& Jin, S. (2010). Effect of soy isoflavones on breast cancer recurrence and death for patients receiving adjuvant endocrine therapy. Canadian Medical Association Journal, Vol.182, No.17, (November 23, 2010), pp.18571862

Kao, T. H., Wu, W. M., Hung, C. F., Wu, W. B., \& Chen, B. H. (2007). Anti-inflammatory Effects of Isoflavone Powder Produced from Soybean Cake. Journal of Agricultural and Food Chemistry, Vol.55, No.26, pp.11068-11079

Kenny, A. M., Mangano, K. M., Abourizk, R. H., Bruno, R. S., Anamani, D. E., Kleppinger, A., Walsh, S. J., Prestwood, K. M., \& Kerstetter, J. E. (2009). Soy proteins and isoflavones affect bone mineral density in older women: a randomized controlled trial. The American Journal of Clinical Nutrition, Vol.90, No.1, (July 1, 2009), pp.234242

Kim, K., Lim, K. M., Kim, C. W., Shin, H. J., Seo, D. B., Lee, S. J., Noh, J. Y., Bae, O.N., Shin, S., \& Chung, J. H. (2010). Black soybean extract can attenuate thrombosis through inhibition of collagen-induced platelet activation. The Journal of Nutritional Biochemistry, Vol.In Press, Corrected Proof,

Kim, S. M., Rico, C. W., Lee, S. C., \& Kang, M. Y. (2010). Modulatory Effect of Rice Bran and Phytic Acid on Glucose Metabolism in High Fat-Fed C57BL/6N Mice. Journal of Clinical Biochemistry and Nutrition, Vol.47, No.1, pp.12-17

Kitts, D. D., \& Weiler, K. (2003). Bioactive Proteins and Peptides from Food Sources. Applications of Bioprocesses used in Isolation and Recovery. Current Pharmaceutical Design, Vol.9, pp.1309-1323

Koh, W. P., Wu, A. H., Wang, R., Ang, L.-W., Heng, D., Yuan, J.-M., \& Yu, M. C. (2009). Gender-specific Associations Between Soy and Risk of Hip Fracture in the Singapore Chinese Health Study. American Journal of Epidemiology, Vol.170, No.7, (October 1, 2009), pp.901-909

Korhonen, H., \& Pihlanto, A. (2003). Food-derived Bioactive Peptides - Opportunities for Designing Future Foods. Current Pharmaceutical Design, Vol.9, pp.1297-1308

Kwon, D. Y., Hong, S. M., Ahn, I. S., Kim, M. J., Yang, H. J., \& Park, S. (2011). Isoflavonoids and peptides from meju, long-term fermented soybeans, increase insulin sensitivity and exert insulinotropic effects in vitro. Nutrition (Burbank, Los Angeles County, Calif.), Vol.27, No.2, pp.244-252

Lebiedzinska, A., \& Szefer, P. (2006). Vitamins B in grain and cereal-grain food, soyproducts and seeds. Food Chemistry, Vol.95, No.1, pp.116-122 
Lee, J. S. (2006). Effects of soy protein and genistein on blood glucose, antioxidant enzyme activities, and lipid profile in streptozotocin-induced diabetic rats. Life Sciences, Vol.79, No.16, pp.1578-1584

Lee, S. H., Parka, H. J., Chuna, H. K., Choa, S. Y., Junga, H. J., Choa, S. M., Kimb, D. Y., Kangb, M. S., \& Lillehojc, H. S. (2007). Dietary phytic acid improves serum and hepatic lipid levels in aged ICR mice fed a high-cholesterol diet. Nutrition Research, Vol.27, No.8, pp.505-510

Levis, S., \& Griebeler, M. L. (2010). The Role of Soy Foods in the Treatment of Menopausal Symptoms. The Journal of Nutrition, Vol.140, No.12, (December 1, 2010), pp.23182321

Liavonchanka, A., \& Feussner, I. (2006). Lipoxygenases: Occurrence, functions and catalysis. Journal of Plant Physiology, Vol.163, No.3, pp.348-357

Liu, K. (1997). Soybeans: chemistry, technology, and utilization Chapman \& Hall, New York.

Loiseau, J., Ly Vu, B., Macherel, M. H., \& Deunff, Y. L. (2001). Seed lipoxygenases: occurrence and functions. Seed Science Research, Vol.11, No.03, pp.199-211

Ma, W. W., Xiang, L., Yu, H. L., Yuan, L. H., Guo, A. M., Xiao, Y. X., Li, L., \& Xiao, R. (2009). Neuroprotection of soyabean isoflavone co-administration with folic acid against beta-amyloid 1-40-induced neurotoxicity in rats. Br J Nutr, Vol.102, No.4, pp.502505

Machado, F. P. P., Queiróz, J. H., Oliveira, M. G. A., Piovesan, N. D., Peluzio, M. C. G., Costa, N. M. B., \& Moreira, M. A. (2008). Effects of heating on protein quality of soybean flour devoid of Kunitz inhibitor and lectin. Food Chemistry, Vol.107, No.2, pp.649-655

Martin, C. A., Almeida, V. V. d., Ruiz, M. R., Visentainer, J. E. L., Matshushita, M., Souza, N. E. d., \& Visentainer, J. V. (2006). Ácidos graxos poliinsaturados ômega-3 e ômega-6: importância e ocorrência em alimentos. Revista de Nutrição, Vol.19, pp.761-770

Martinez Dominguez, B., Ibañez Gomes, M., \& Rincón León, F. (2002). Acido fítico: aspectos nutricionales e implicaciones analíticas. Arch. Latinoam. Nutr., Vol.52, No.3, pp.219231

Martino, H. S. D., Martin, B. R., Weaver, C. M., Bressan, J., Esteves, E. A., \& Costa, N. M. B. (2007). Zinc and iron bioavailability of genetically modified soybeans in rats. Journal of Food Science, Vol.72, No.9, pp.689-695

Martino, H. S. D., Martin, B. R., Weaver, C. M., Bressan, J., Moreira, M. A., \& Costa, N. M. B. (2008). A Soybean Cultivar Lacking Lipoxygenase 2 and 3 Has Similar Calcium Bioavailability to a Commercial Variety Despite Higher Calcium Absorption Inhibitors. Journal of Food Science, Vol.73, No.3, pp.33-35

Maskarinec, G., Verheus, M., Steinberg, F. M., Amato, P., Cramer, M. K., Lewis, R. D., Murray, M. J., Young, R. L., \& Wong, W. W. (2009). Various Doses of Soy Isoflavones Do Not Modify Mammographic Density in Postmenopausal Women. The Journal of Nutrition, Vol.139, No.5, (May 2009), pp.981-986

Massey, L. K., Roman-Smith, H., \& Sutton, R. A. L. (1993). Effect of dietary oxalate and calcium on urinary oxalate and risk of formation of calcium oxalate kidney stones. Journal of the American Dietetic Association, Vol.93, No.8, pp.901-906

Mateos-Aparicio, I., Redondo Cuenca, A., Villanueva-Suárez, M. J., \& Zapata-Revilla, M. A. (2008). Soybean, a promising health source. Nutrición Hospitalaria, Vol.23, pp.305312 
Mendes, F. Q., Oliveira, M. G. A., Cardoso, L. R., Costa, N. M. B., \& Sant'ana, R. C. O. (2007). Digestibilidade protéica e caracterização bromatológica de linhagens de soja copm ausência ou presença do inibidor de tripsina Kunitz e das isozimas lipoxigenases. Journal of Biosciences, Vol.23, pp.14-21

Mendes, W. S. (2004). Composição química e valor nutritivo da soja crua e submetida a diferentes tratamentos térmicos para suínos em crescimento. Arquivos Brasileiros de Medicina Veterinária e Zootecnia, Vol.56, pp.207-213

Messina, M. J., Persky, V., Setchell, K. D., \& Barnes, S. (1992). Soy intake and cancer risk: a review of the in vitro and in vivo data. Nutr Cancer, Vol.21, No.2, pp.113-131

Miura, E. M. Y., Ferreira Da Silva, R. S. D. S., Mizubuti, I. Y., \& Ida, E. I. (2005). Cinética de Inativação de Inibidores de Tripsina e de Insolubilização de Proteínas de Diferentes Cultivares de Soja. Revista brasileira de zootecnia, Vol.34, No.5, pp.1659-1665

Monteiro, M. R. P., Costa, N. M. B., Oliveira, M. G. D. A., Pires, C. V., \& Moreira, M. A. (2004). Qualidade protéica de linhagens de soja com ausência do Inibidor de Tripsina Kunitz e das isoenzimas Lipoxigenases. Revista de Nutrição, Vol.17, No.2, pp.195-205

Monteiro, M. R. P., Moreira, M. A., Costa, N. M. B., Oliveira, M. G. A., \& Pires, C. V. (2003). Avaliação da Digestibilidade Protéica de Genótipos de Soja com Ausência e Presença do Inibidor de Tripsina Kunitz e Lipoxigenases. Brazilian Journal of Food Technology, Vol.6, No.1, (out), pp.99-107

Moriyama, T., Kishimoto, K., Nagai, K., Urade, R., Ogawa, T., Utsumi, S., Maruyama, N., \& Maebuchi, M. (2004). Soybean beta;-Conglycinin Diet Suppresses Serum Triglyceride Levels in Normal and Genetically Obese Mice by Induction of beta;Oxidation, Downregulation of Fatty Acid Synthase, and Inhibition of Triglyceride Absorption. Bioscience, Biotechnology, and Biochemistry, Vol.68, No.2, pp.352-359

Müller, L. (1981). Taxionomia e morfologia. In: A soja no Brasil, S. M. Miyasaka, J. C., (pp. 65104). Instituto de Tecnologia de Alimentos, Campinas.

Nagasawa, A., Fukui, K., Kojima, M., Kishida, K., Maeda, N., Nagaretani, H., Hibuse, T., Nishizawa, H., Kihara, S., Waki, M., Takamatsu, K., Funahashi, T., \& Matsuzawa, Y. (2003). Divergent effects of soy protein diet on the expression of adipocytokines. Biochemical and Biophysical Research Communications, Vol.311, No.4, pp.909-914

Nakata, P. A. (2003). Advances in our understanding of calcium oxalate crystal formation and function in plants. Plant Science, Vol.164, No.6, pp.901-909

Nielsen, N. C. (1996). Soybean seed composition. In: Soybean: genetics, molecular biology and biotechnology, D. P. S. Verma, \& R. C. Shoemaker. CAB International, Wallingford.

Oh, H. J., Kim, T. H., Sohn, Y. W., Kim, Y. S., Oh, Y. R., Cho, E. Y., Shim, S. Y., Shin, S. R., Han, A. L., Yoon, S. J., \& Kim, H. C. (2011). Association of serum alanine aminotransferase and $\gamma$-glutamyltransferase levels within the reference range with metabolic syndrome and nonalcoholic fatty liver disease. Korean J Hepatol, Vol.17, No.1, (Mar), pp.27-36

Oku, T., Nakamura, M., Takasugi, A., Hashiguchi-Ishiguro, M., Tanabe, K., \& Nakamura, S. (2009). Effects of cake made from whole soy powder on postprandial blood glucose and insulin levels in human subjects. International Journal of Food Sciences and Nutrition, Vol.60, No.s4, pp.224-231 
Oliveira, M. I. P., Piovesan, N. D., José, I. C., Barros, E. G., Moreira, M. A., \& Oliveira, L. O. (2007). Protein, oil, and isoflavone contents in lipoxygenase- and Kunitz trypsin inhibitor-deficient soybean seeds. Chromatographia, Vol.66, pp.521-527

Paucar-Menacho, L. M., Amaya-Farfán, J., Berhow, M. A., Mandarino, J. M. G., Mejia, E. G. d., \& Chang, Y. K. (2010). A high-protein soybean cultivar contains lower isoflavones and saponins but higher minerals and bioactive peptides than a lowprotein cultivar. Food Chemistry, Vol.120, No.1, pp.15-21

Paula, S. A. (2007). Composição bioquímica e fatores antinutricionais de genótipos de soja. Bioquímica Agrícola. Viçosa: Universidade Federal de Viçosa.

Penha, L. A. O., Fonseca, I. C. B., Mandarino, J. M., \& Benassi, V. T. (2007). A soja como alimento: valor nutricional, benefícios para a saúde e cultivo orgânico. Boletim do Centro de Pesquisa de Processamento de Alimentos, Vol.25, (jan/jun), pp.91-102

Pereira, C. A. S. P., \& Oliveira, F. B. (2002). Soja, alimento e saúde: valor nutricional e preparo UFV, Viçosa.

Quirrenbach, H. R., Kanumfre, F., Rosso, N. D., \& Carvalho Filho, M. A. (2009). Comportamento do ácido fítico na presença de Fe(II) e Fe (III). Ciência e Tecnologia de Alimentos, Vol.29, No.1, pp.24-32

Reinwald, S., Akabas, S. R., \& Weaver, C. M. (2010). Whole Versus the Piecemeal Approach to Evaluating Soy. The Journal of Nutrition, Vol.140, No.12, (December 1, 2010), pp.2335-2343

Reinwald, S., \& Weaver, C. M. (2010). Soy Components vs. Whole Soy: Are We Betting Our Bones on a Long Shot? The Journal of Nutrition, Vol.140, No.12, (December 1, 2010), pp.2312-2317

Reynolds, K., Chin, A., Lees, K. A., Nguyen, A., Bujnowski, D., \& He, J. (2006). A MetaAnalysis of the Effect of Soy Protein Supplementation on Serum Lipids. The American Journal of Cardiology, Vol.98, No.5, pp.633-640

Rios, D. R., Rodrigues, E. T., Cardoso, A. P., Montes, M. B., Franceschini, S. A., \& Toloi, M. R. (2008). Lack of effects of isoflavones on the lipid profile of Brazilian postmenopausal women. Nutrition, Vol.24, No.11-12, (Nov-Dec), pp.1153-1158

Ritt, A. B. B. (2005). Urease de soja [Glycine Max (L.) Merril]: expressão em tabaco (Nicotiana tabacum) e atividade fungicida e/ou fungistática. Programa de pósgraduação em biologia celular e molecular: Universidade Federal do Rio Grande do Sul.

Runho, C. R. (2009). Farelo de soja: Processamento e qualidade.

Sacks, F. M., Lichtenstein, A., Van Horn, L., Harris, W., Kris-Etherton, P., Winston, M., \& for the American Heart Association Nutrition Committee. (2006). Soy Protein, Isoflavones, and Cardiovascular Health: An American Heart Association Science Advisory for Professionals From the Nutrition Committee. Circulation, Vol.113, No.7, (February 21, 2006), pp.1034-1044

Saito, K., Jin, D. H., Ogawa, T., Muramoto, K., Hatakeyama, E., Yasuhara, T., \& Nokihara, K. (2003). Antioxidative Properties of Tripeptide Libraries Prepared by the Combinatorial Chemistry. Journal of Agricultural and Food Chemistry, Vol.51, No.12, pp.3668-3674

Silva, M. R., \& Silva, M. A. A. P. (2000). Fatores antinutricionais: inibidores de proteases e lectinas. Revista de Nutrição, Vol.13, pp.3-9 
Silva, M. S., Naves, M. M. V., De Oliveira, R. B., \& De Leite, O. S. M. (2006). Composição química e valor protéico do resíduo de soja em relação ao grão de soja. Ciência e Tecnologia de Alimentos, Vol.26, No.3, pp.571-576

Simmen, F. A., Mercado, C. P., Zavacki, A. M., Huang, S. A., Greenway, A. D., Kang, P., Bowman, M. T., \& Prior, R. L. (2010). Soy protein diet alters expression of hepatic genes regulating fatty acid and thyroid hormone metabolism in the male rat. The Journal of Nutritional Biochemistry, Vol.21, No.11, pp.1106-1113

Sirtori, C. R., Eberini, I., \& Arnoldi, A. (2007). Hypocholesterolaemic effects of soya proteins: results of recent studies are predictable from the anderson meta-analysis data. $\mathrm{Br} \mathrm{J}$ Nutr Vol.97, No.5, pp.816-822

Sirtori, C. R., Galli, C., Anderson, J. W., \& Arnoldi, A. (2009). Nutritional and nutraceutical approaches to dyslipidemia and atherosclerosis prevention: Focus on dietary proteins. Atherosclerosis, Vol.203, No.1, pp.8-17

Song, Y. S., Frias, J., Martinez-Villaluenga, C., Vidal-Valdeverde, C., \& de Mejia, E. G. (2008). Immunoreactivity reduction of soybean meal by fermentation, effect on amino acid composition and antigenicity of commercial soy products. Food Chemistry, Vol.108, No.2, pp.571-581

Steinberg, F. M., Guthrie, N. L., Villablanca, A. C., Kumar, K., \& Murray, M. J. (2003). Soy protein with isoflavones has favorable effects on endothelial function that are independent of lipid and antioxidant effects in healthy postmenopausal women. The American Journal of Clinical Nutrition, Vol.78, No.1, (July 1, 2003), pp.123-130

Steinberg, F. M., Murray, M. J., Lewis, R. D., Cramer, M. A., Amato, P., Young, R. L., Barnes, S., Konzelmann, K. L., Fischer, J. G., Ellis, K. J., Shypailo, R. J., Fraley, J. K., Smith, E. O. B., \& Wong, W. W. (2010). Clinical outcomes of a 2-y soy isoflavone supplementation in menopausal women. The American Journal of Clinical Nutrition, Vol.93, No.2, (December 1, 2010), pp.356-360

Su, Y., Shankar, K., \& Simmen, R. C. M. (2009). Early Soy Exposure via Maternal Diet Regulates Rat Mammary Epithelial Differentiation by Paracrine Signaling from Stromal Adipocytes. The Journal of Nutrition, Vol.139, No.5, (May 2009), pp.945-951

Takahashi, T., Nakamura, A., Kato, M., Maeda, H., Mandella, R. C., Broadmeadow, A., \& Ruckman, S. A. (2003). Soluble soybean fiber: a 3-month dietary toxicity study in rats. Food Chem Toxicol, Vol.41, No.8, (Aug), pp.1111-1121

Takenaka, Y., Doyama, N., Maruyama, N., Utsumi, S., \& Yoshikawa, M. (2004). Introduction of DPR, an enterostatin fragment peptide, into soybean beta-conglycinin alpha' subunit by site-directed mutagenesis. Bioscience, Biotechnology, and Biochemistry, Vol.68, No.1, pp.253-256

Teixeira, A. I. (2003). Herdabilidade e correlação entre concentrações de proteína em soja avaliadas por diferentes metodologias. Dissertação (Bioquímica Agrícola) (p. 53). Viçosa: Universidade Federal de Viçosa.

Teixeira Damasceno, N., Apolinário, E., Dias Flauzino, F., Fernandes, I., \& Abdalla, D. (2007). Soy isoflavones reduce electronegative low-density lipoprotein (LDL-) and anti-LDL- autoantibodies in experimental atherosclerosis. European Journal of Nutrition, Vol.46, No.3, pp.125-132 


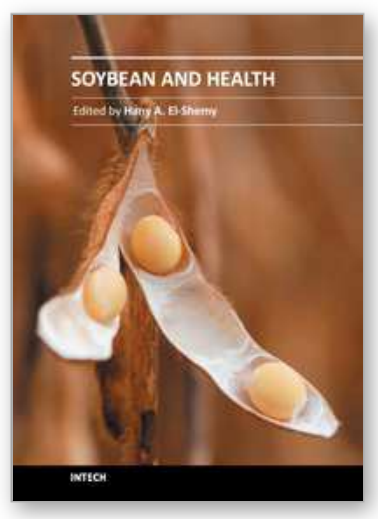

\author{
Soybean and Health \\ Edited by Prof. Hany El-Shemy
}

ISBN 978-953-307-535-8

Hard cover, 502 pages

Publisher InTech

Published online 12, September, 2011

Published in print edition September, 2011

Worldwide, soybean seed proteins represent a major source of amino acids for human and animal nutrition. Soybean seeds are an important and economical source of protein in the diet of many developed and developing countries. Soy is a complete protein, and soy-foods are rich in vitamins and minerals. Soybean protein provides all the essential amino acids in the amounts needed for human health. Recent research suggests that soy may also lower risk of prostate, colon and breast cancers as well as osteoporosis and other bone health problems, and alleviate hot flashes associated with menopause. This volume is expected to be useful for student, researchers and public who are interested in soybean.

\title{
How to reference
}

In order to correctly reference this scholarly work, feel free to copy and paste the following:

Hércia Stampini Duarte Martino, Leandro de Morais Cardoso, Sônia Machado Rocha Ribeiro, Maria Inês de Souza Dantas, Newton Deniz Piovesan and Elvira De Mejia (2011). Nutritional and Bioactive Compounds of Soybean: Benefits on Human Health, Soybean and Health, Prof. Hany El-Shemy (Ed.), ISBN: 978-953-307535-8, InTech, Available from: http://www.intechopen.com/books/soybean-and-health/nutritional-and-bioactivecompounds-of-soybean-benefits-on-human-health

\section{INTECH}

open science | open minds

\section{InTech Europe}

University Campus STeP Ri

Slavka Krautzeka 83/A

51000 Rijeka, Croatia

Phone: +385 (51) 770447

Fax: +385 (51) 686166

www.intechopen.com

\section{InTech China}

Unit 405, Office Block, Hotel Equatorial Shanghai

No.65, Yan An Road (West), Shanghai, 200040, China

中国上海市延安西路65号上海国际贵都大饭店办公楼405单元

Phone: +86-21-62489820

Fax: +86-21-62489821 
(C) 2011 The Author(s). Licensee IntechOpen. This chapter is distributed under the terms of the Creative Commons Attribution-NonCommercialShareAlike-3.0 License, which permits use, distribution and reproduction for non-commercial purposes, provided the original is properly cited and derivative works building on this content are distributed under the same license. 